\title{
EFEKTIVITAS PENDEKATAN KONTEKSTUAL (CONTEXTUAL TEACHING AND LEARNING) DALAM MENULIS PUISI
}

\author{
Hasnah $\mathbf{P}^{*}$ \\ Guru SMA Negeri 1 Wonomulyo Polewali Mandar \\ *Email: Hasnah.pae@gmail.com
}

\begin{abstract}
This study aims to describe the effectiveness of contextual learning in writing poetry in class $X$ students of SMA Negeri 1 Wonomulyo Polewali Mandar. The design used in this study is an experimental design of the experimental-control posttest group design. Students who were sampled were 60 people divided into two groups, namely the first group as many as 30 people as an experimental group / class and the second group as many as 30 people as a control group/class. The results showed that the average value of student competence in writing poetry through the application of a contextual approach (experimental class) was 7,9 while the average value of students' ability to write poetry without the application of a contextual approach (control class) was 6,5. The results of the comparison of the coefficient of the average value of students (tcount) between the experimental class $\left(\mathrm{X}_{1}\right)$ and the control class $\left(\mathrm{X}_{2}\right)$ obtained by 4,51 is greater than the table at the 5\% significance level and 95\% confidence obtained ts 0,95=1,70. Because tcount is greater than ttable at the 5\% significance level and 95\% confidence, the null hypothesis $\left(H_{0}\right)$ is rejected and the hypothesis $\left(H_{1}\right)$ is accepted. So, the contextual approach is effectively applied in learning to write poetry for class X students of SMA Negeri 1 Wonomulyo.
\end{abstract}

Keywords: effectiveness, contextual, writing poetry

\section{PENDAHULUAN}

Pengembangan pembelajaran memfokuskan pada kompetensi tertentu, berupa pengetahuan, keterampilan, dan sikap yang utuh dan terpadu serta dapat didemonstrasikan peserta didik sebagai wujud hasil belajar. Penerapan kurikulum kurikulum 2013 memungkinkan para guru merencanakan, melaksanakan, dan menilai hasil belajar peserta didik dalam mencapai standar kompetensi, dan kompetensi dasar sebagai cermin penguasaan dan pemahaman terhadap apa yang dipelajari. Perubahan kurikulum pun berdampak pada lahirnya berbagai jenis pendekatan, metode, dan strategi belajar mengajar. 
Pendekatan adalah seperangkat asumsi atau kerangka teori tentang hakikat, pengajaran, serta belajar yang mendasari penyusunan suatu metode pengajaran tertentu (Djumingin, (2007: 3). Pendekatan merupakan falsafah seorang guru dalam mengajar. Berkembang sebuah pandangan bahwa keberhasilan seorang guru dalam mengajar itu bergantung pada kemampuan seorang guru mengemas dan menyajikan materi itu dengan menarik dan tidak monoton. Salah satu pendekatan yang memberdayakan siswa adalah pendekatan kontekstual (CTL). Contextual Teaching and Learning (CTL) merupakan proses pembelajaran yang holistik dan bertujuan membantu siswa untuk memahami makna materi ajar dengan mengaitkannya terhadap konteks kehidupan mereka sehari-hari (konteks pribadi, sosial, dan kultural). Pendekatan kontekstual dikembangkan dengan tujuan agar pembelajaran lebih produktif dan bermakna.

Pembelajaran menulis puisi sebagai bagian yang tak terpisahkan dari pelajaran Bahasa Indonesia yang sampai sekarang ini dirasakan kurang mendapat perhatian dari siswa. Mereka seakan tidak merasa antusias bahkan terlihat rasa keengganan dalam berpuisi, hal ini mungkin disebabkan karena mereka terbiasa untuk berapresiasi yang melibatkan aspek akal, rasa, dan keterampilan. Padahal menurut teori belajar mutakhir (Peter Sheal, dalam Erman, 2004: 7) mengemukakan bahwa belajar yang paling bermakna hingga mencapai $90 \%$ adalah dengan cara melakukan, mengalami, dan mengkomunikasikan. Agar pembelajaran sesuai dengan prinsip tersebut, mata pelajaran haruslah disesuaikan dan diangkat dari konteks aktual yang dialami siswa dalam kehidupannya.

Rendahnya kemampuan siswa dalam menulis puisi tersebut disebabkan oleh kurang efektifnya pembelajaran yang diciptakan guru. Ketidakefektifan itu disebabkan oleh kurang tepatnya strategi yang diterapkan guru dalam pembelajaran. Strategi yang dipakai guru tidak dapat mengembangkan potensipotensi yang ada pada diri siswa agar secara leluasa dapat mengekspresikan perasaannya.

Berdasarkan hasil pengamatan selaku guru selama melaksanakan pembelajaran di SMA Negeri 1 Wonomulyo dengan melihat kemanpuan siswa dari hasil penilaian akhir pembelajaran, ternyata masih banyak siswa yang belum mempunyai kemampuan dalam menulis puisi khususnya di kelas $\mathrm{X}$.

Dalam penelitian ini diharapkan dapat bermanfaat, baik secara teoretis maupun secara praktis. Secara teoretis, hasil penelitian ini diharapkan dapat memperkaya jenis-jenis pendekatan dalam proes belajar mengajar. Adapun manfaat praktisnya, yaitu: Bagi guru; penerapan pendekatan konteksual dapat meningkatkan kemampuan kreatifitas siswa dalam menulis dan mempresentasekan puisi. Ini adalah pembelajaran inovatif yang mungkin bisa diterapkan dalam materi lain. Bagi siswa; akan tumbuh kesadaran bahwa dengan belajar puisi, dapat menumbuhkan dan mengembangkan kecerdasan intelektual, emosional, dan spiritual sebagai instrumen untuk membentuk pribadi yang positif. 
Bagi dunia pendidikan; bahwa paradigma sekarang berubah dari pengajaran menjadi pembelajaran yang berarti bahwa siswa belajar tidak cukup dengan memperhatikan, menulis, membaca, dan berlatih tetapi pembelajaran adalah melibatkan siswa (sebagai subjek) dengan cara melakukan, mengalami, dan mengkomunikasikan kehidupan nyata siswa menjadi sebuah konsep.

Puisi ialah sebuah bentuk karya sastra yang mengungkapkan suatu pikiran serta perasaan dari penyair dan secara imajinatif serta disusun dengan mengonsentrasikan sebuah kekuatan bahasa dengan pengonsentrasian suatu struktur fisik serta struktur batinnya. Atau dengan kata lain puisi adalah karya sastra dengan bahasa yang dipadatkan, dipersingkat, dan diberi irama dengan bunyi yang padu dan pemilihan kata-kata kias (imajinatif). Kata-kata yang digunakan betul-betul kata-kata yang terpilih, singkat dan padat, memiliki kekuatan dalam pengucapannya. Karena itu salah satu usaha dari penyair adalah memilih kata-kata yang memiliki persamaan bunyi (rima). Kata-kata itu mewakili makna yang luas. Karena itu, kata-kata tersebut dicarikan konotasi atau makna tambahan dan dirangkai dalam gaya bahasa figuratif (Waluyo, 2005: 67).

Puisi memiliki dua Unsur ini yaitu struktur fisik dan struktur batin puisi, berikut ini penjelasannya :

\section{Struktur Fisik Puisi}

a. Perwajahan Puisi (Tipografi), yaitu suatu bentuk puisi yang seperti halaman yang tidak dipenuhi dengan kata-kata, tepi kanan-kiri, pengaturan barisnya, hingga pada baris puisi yang tidak selalu dimulai dengan huruf kapital dan diakhiri dengan tanda titik. Hal tersebut menentukan sebuah pemaknaan terhadap puisi.

b. Diksi adalah pemilihat kata-kata yang dilakukan oleh sih penyair dalam sebuah puisinya. Karena puisi ialah sebuah bentuk karya sastra yang sedikit kata-katanya bisa mengungkapkan banyak, oleh karena itu katakatanya harus dipilih secermat mungkin. Pada pemilihan kata-kata dalam sebuah puisi erat kaitannya dengan makna, keselarasan bunyi, dan urutan kata.

c. Imaji, ialah sebuah kata atau susunan kata yang mengungkapkan sebuah pengalaman indrawi, misalnya sebuah penglihatan, pendengaran, dan perasaan. Imaji ini terbagi atas tiga yaitu imaji suara (auditif), imaji penglihatan (visual), dan imaji raba atau sentuh (imaji taktil). Imaji mengakibatkan sih pembaca seakan-akan melihat, mendengar, dan merasakan apa yang dialami oleh penyair.

d. Kata Konkret, ialah sebuah kata yang memungkinkan memunculkan sebuah imaji karena bisa ditangkap indera yang mana kata ini berhubungan dengan suatu kiasan atau lambang. Seperti kata konkret "salju" yang dimana melambangkan sebuah kebekuan cinta, kehampaan 
hidup, dll, sedangkan pada kata kongkret "rawa-rawa" melambangkan sebuah tempat kotor, tempat hidup, bumi, kehidupan dan lain sebaginya.

e. Gaya Bahasa, ialah suatu penggunaan bahasa dengan menghidupkan atau meningkatkan suatu efek dan menimbulkan sebuah konotasi tertentu dengan bahasa figuratif yang menyebabkan sebuah puisi menjadi prismatis, yang artinya memancarkan banyak makna atau kaya makna. Gaya bahasa ini disebut dengan majas. macam-macam majas yaitu antara lain metafora, simile, personifikasi, litotes, ironi, sinekdoke, eufemisme, repetisi, anafora, pleonasme, antitesis, alusio, klimaks, antiklimaks, satire, pars pro toto, totem pro parte, hingga paradoks

f. Rima/Irama ialah sebuah persamaan bunyi puisi yang baik di awal, tengah, dan akhir baris puisi. Rima mencakup yakni: Onomatope (sebuah tiruan terhadap bunyi seperti /ng/ yang memberikan suatu efek magis puisi staudji C. B); Bentuk intern pola bunyi (aliterasi, asonansi, persamaan akhir, persamaan awal, sajak berselang, sajak berparuh, sajak penuh, repetisi bunyi (kata), dan sebagainya; Pengulangan sebuah kata/ungkapan ritma ialah tinggi rendah, panjang pendek, keras lemahnya bunyi. Rima sangat menonjol dalam pembacaan sebuah puisi.

\section{Struktur Batin Puisi}

a. Tema/Makna (sense); media pusi ialah suatu bahasa. Tataran bahasa ialah suatu hubungan tanda dengan makna, maka pusi harus mempunyai sebuah makna ditipa kata, baris, bait, dan makna keseluruhan.

b. Rasa (Feeling) yaitu suatu sikap penyair yang mengenai pokok permasalahan yang terdapat di dalam puisinya. Pengungkapan tema dan rasa erat kaitannya akan sebuah latar belakang sosial dan psikologi penyair, misalnya seperti latar belakang pendidikan, agama, jenis kelamin, kelas sosial, kedudukan dalam sebuah masyarakat, usia, pengalaman sosiologis dan psikologis, dan dalam pengetahuan. Pada kedalaman pengungkapan sebuah tema dan ketetapan dalam menyikapi sebuah masalah tidak tergantung dari sebuah kemampuan penyair memilih sebuah kata-kata, rima, gaya bahasa, dan bentuk puisi saja, namun juga dari sebuah wawasan, pengetahuan, pengalaman, dan keperibadian yang terbentuk oleh suatu latar belakang sosiologis dan psikologisnya.

c. Nada (tone) ialah suatu sikap penyair terdapat pembacanya. Nada berhubungan dengan tema dan rasa. Penyair bisa menyampaikan suatu tema baik dengan suatu nada yang menggurui, mendikte, bekerja sama dengan pembaca dalam pemecahan sebuah masalah, menyerahkan masalah kepada sih pembaca, dengan nada sombong, menganggap bodoh dan rendah pembaca, dan lain sebagainya. 
d. Amanat/tujuan maksud (intention) yaitu sebuah pesan yang akan disampaikan oleh sih penyair kepada sih pembaca yang terdapat di dalam puisi tersebut.

\section{Pembelajaran Puisi}

Pembelajaran menulis puisi adalah upaya yang dilakukan guru agar terjadi proses perolehanilmu dan pengetahuan, penguasaan kemahiran, pembentukan sikap dan kepercayaan peserta didik dalam menulis puisi.

Pembelajaran menulis puisi memiliki banyak manfaat, antara lain: (1) sebagai alat pengungkapan diri, (2) sebagai alat untuk memahami secara lebih jelas dan mendalami ide-ide yang ditulisnya, bisa berhubungan dengan dirinya, orang lain, bahkan dengan Tuhannya, (3) sebagai alat untuk meningkatkan kesadaran diri terhadap lingkungan, (4) sebagai alat untuk melibatkan diri secara aktif dalam kegiatan bersastra, (5) sebagai alat untuk mengembangkan kemampuan dan keterampilan menggunakan bahasa sebagai media komunikasi, dan (6) meningkatkan inisiatif penulis (Roekhan, dalam Pradopo, 1998: 63).

\section{Pendekatan Kontekstual}

Pendekatan adalah seperangkat asumsi atau kerangka teori tentang hakikat, pengajaran, serta belajar yang mendasari penyusunan suatu metode pengajaran tertentu (Sulastriningsih, 2007: 3). Contextual Teaching and Learning (CTL) merupakan proses pembelajaran yang holistik dan bertujuan membantu siswa untuk memahami makna materi ajar dengan mengaitkannya terhadap konteks kehidupan mereka sehari-hari (konteks pribadi, sosial dan kultural). Sehingga siswa memiliki pengetahuan/ ketrampilan yang dinamis dan fleksibel untuk mengkonstruksi sendiri secara aktif pemahamannya.

CTL disebut pendekatan kontekstual karena konsep belajar yang membantu guru mengaitkan antara materi yang diajarkannya dengan situasi dunia nyata siswa dan mendorong siswa membuat hubungan antara pengetahuan yang dimilikinya dengan penerapannya dalam kehidupan mereka sebagai anggota masyarakat.

Dalam contextual teaching and learning diperlukan sebuah pendekatan yang lebih memberdayakan siswa dengan harapan siswa mampu mengkonstruksikan pengetahuan dalam benak mereka, bukan menghafalkan fakta. Di samping itu siswa belajar melalui mengalami bukan menghafal, mengingat pengetahuan bukan sebuah perangkat fakta dan konsep yang siap diterima akan tetapi sesuatu yang harus dikonstruksi oleh siswa.

Dalam kelas kontekstual, tugas guru adalah membantu siswa mencapai tujuannya. Maksudnya, guru lebih banyak berurusan dengan strategi daripada memberi informasi. Tugas guru mengelola kelas sebagai sebuah tim yang bekerja bersama untuk menemukan sesuatu yang baru bagi anggota kelas (siswa). Sesuatu 
yang baru datang dari menemukan sendiri bukan dari apa kata guru. Begitulah peran guru di kelas yang dikelola dengan pendekatan kontekstual.

\section{METODE PENELITIAN}

Penelitian ini merupakan penelitian eksperimen yang melibatkan dua kelompok, yaitu kelompok/kelas eksperimen (kelompok/kelas yang diberi tindakan berupa penerapan pendekatan kontekstual dalam pembelajaran menulis puisi) dan kelompok/kelas kontrol (kelompok/kelas yang tidak diterapkan pendekatan kontekstual dalam pembelajaran menulis puisi). Populasi penelitian adalah siswa kelas X SMA Negeri 1 Wonomulyo, Polewali Mandar yang menjadi populasi dalam penelitian ini yang berjumlah 324 siswa yang tersebar dalam sembilan kelas. Tahun Pelajaran 2017/2018

Penarikan sampel dilakukan dengan cara purposif (purposive sample). Siswa yang dijadikan sampel sebanyak 60 orang yang terbagi ke dalam dua kelompok, yaitu sebanyak 30 orang sebagai kolompok/kelas eksperimen dan sebanyak 30 orang sebagai kelompok/kelas kontrol. Penarikan sampel didasarkan pendapat Arikunto (2006: 134), yaitu apabila subjek penelitian kurang dari 100 orang, maka lebih baik diambil semuanya sehingga penelitiannya merupakan populasi. Selanjutnya jika jumlah subjek cukup besar, maka diambil sampel antara 10-15\% atau antara $20-25 \%$ atau lebih, bergantung dari waktu, biaya, dan tenaga yang tersedia.

Teknik yang digunakan untuk mengumpulkan data dalam penelitian ini adalah teknik penilaian hasil belajar yang menuntut siswa mampu mencapai semua indikator pembelajaran.

Adapun langkah-langkah (prosedur) pengumpulan data dalam penelitian ini adalah:

1. Peneliti melakukan observasi lapangan untuk mengetahui jumlah siswa dan keadaan siswa.

2. Peneliti menerapkan pembelajaran konvensional dalam menulis puisi pada kelas kontrol dan menerapkan pembelajaran kontekstual dalam menulis puisi pada kelas eksperimen.

3. Peneliti memberikan materi pembelajaran pada kelas eksperimen selama tiga kali pertemuan

4. Peneliti memberikan tes kepada siswa untuk menulis puisi, baik pada kelas kontrol maupun kelas eksperimen.

5. Tes yang diberikan tersebut dikerjakan dalam waktu $2 \times 45$ menit. Waktu yang digunakan disesuaikan dengan jam pelajaran bahasa Indonesia di sekolah tersebut.

6. Peneliti mengumpulkan hasil tes siswa. 
7. Pada akhirnya, peneliti melakukan kegiatan analisis data dengan menggunakan analisis deskriptif dan analisis eksperimen jenis uji $t$ desain ketiga.

\section{Teknik Analisis Data}

Dalam penelitian ini, data yang terkumpul dianalisis dengan menggunakan teknik statistik deskriptif dan teknik analisis eksperimen jenis uji t desain ketiga. Langkah-langkah menganalisis data sebagai berikut:

1. Membuat daftar skor mentah.

Skor mentah ditetapkan berdasarkan aspek yang dinilai dari puisi siswa. Penentuan aspek yang dinilai dalam menulis puisi berdasarkan teori tentang struktur fisik dan struktur batin puisi yang dikemukakan oleh Waluyo (1987).

Bobot pada setiap aspek dapat dilihat sebagai berikut:

Tabel 1. Aspek yang dinilai dalam menulis puisi

\begin{tabular}{|c|c|c|}
\hline No & Aspek yang dinilai & Bobot Maksimal \\
\hline 1. & Tema & 10 \\
\hline 2. & Diksi & 15 \\
\hline 3. & Bahasa figuratif & 15 \\
\hline 4. & Nada & 10 \\
\hline 5. & Tifografi & 10 \\
\hline 6. & Kata konkret & 10 \\
\hline 7. & Pengimajian & 15 \\
\hline 8. & Amanat & 15 \\
\hline & Jumlah & 100 \\
\hline
\end{tabular}

2. Membuat distribusi frekuensi dari skor mentah.

3. Data yang diperoleh dari kerja proyeksi, pada umumnya masih dalam keadaan tak menentu. Untuk memudahkan analisis, disusun distribusi frekuensi yang dapat memudahkan perhitungan selanjutnya.

4. Mencari mean rata-rata dengan menggunakan rumus;

$\mathrm{Xi}=60 \% \mathrm{x}$ Skor maksimal

Keterangan:

$\mathrm{Xi}=$ mean ideal

(Nurgiyantoro, 1995: 369)

5. Mengukur penyebaran dengan rumus;

$\mathrm{Si}=\frac{1}{4} \times \mathrm{Xi}$

Keterangan: 


$$
\begin{aligned}
& \mathrm{Si}=\text { simpangan medial } \\
& \mathrm{Xi}=\text { mean medial }
\end{aligned}
$$

(Nurgiyantoro, 1995: 369)

6. Pemberian Interpretasi

Untuk menilai hasil penelitian kelas, baik pada kelas eksperimen maupun kelas kontrol maka perlu pemberian interpretasi dengan rentangan nilai sebagai berikut:

Nilai $9,0-10$ (sangat tinggi)

Nilai 8.0 - 8.9 (tinggi)

Nilia 6.5 - 7.9 (sedang)

Nilai 5.5-6.4 (rendah)

Nilai 0- 5.4 (sangat rendah)

(Nurgyantoro, 1995: 369)

7. Menentukan perbandingan perbandingan nilai rata-rata siswa kelas kontrol dengan kelas eksperimen dengan menggunakan rumus uji $t$ desain ketiga, yaitu;

$$
\mathbf{t}=\frac{M_{1}-M_{2}}{\sqrt{\frac{\sum X_{1}^{2}+\sum X_{2}^{2}}{N(N-1)}}}
$$

\section{HASIL DAN PEMBAHASAN}

Berdasarkan jenis penelitian yang dilakukan, hasil penelitian ini diolah dengan teknik statistik deskriptif dan analisis eksperimen jenis uji $t$ desain ketiga. Penyajian hasil analisis data nilai kelas eksperimen dan hasil nilai kelas kontrol disajikan secara terpisah.

Setelah perolehan nilai dari seluruh sampel penelilitian kelas eksprimen dianalisis melalui analisis data secara berurut mulai dari dengan melihat aspek penilaian menulis puisi, (1) distribusi frekuensi dari skor mentah, (2) mencari mean rata-rata dengan menggunakan rumus $\mathrm{Xi}=60 \% \mathrm{x}$ Skor maksimal, (3) dan mengukur penyebaran dengan rumus $\mathrm{Si}=1 / 4 \times \mathrm{Xi}$ kemudian (4) dilakukan transformasi dari skor mentah di dalam nilai berskala 1-10 setelah itu (5) menilai hasil penelitian kelas eksperimen maupun kelas kontrol, maka perolehan nilai kelas eksprimenm dan kelas kotrol adalah sebagai berikut.

Dari hasil analisis data kelas eksperimen diperoleh gambaran yaitu, tidak ada siswa yang mampu memperoleh skor 100 sebagai skor maksimal. Skor tertinggi yaitu 89,5 yang diperoleh 1 orang siswa dan skor terendah yang diperoleh 1 siswa adalah 67,5 . 
Hasil analisis data kelas eksprimen dari 30 siswa yang dianalisis Skor tertinggi yang diperoleh siswa yaitu 89,5 yang diperoleh 1 orang $(3,33 \%)$; sampel yang mendapat skor 89 berjumlah 1 orang (3,33\%); sampel yang mendapat skor 88 berjumlah 2 orang $(6,66 \%)$; sampel yang mendapat skor 87,5 berjumlah 3 orang $(9,99 \%)$; sampel yang mendapat skor 86 berjumlah 1 orang $(3,33 \%)$; sampel yang mendapat skor 85 berjumlah 1 orang $(3,33 \%)$; sampel yang mendapat skor 83 berjumlah 4 orang (13,33\%); sampel yang mendapat skor 81,5 berjumlah 1 orang $(3,33 \%)$; sampel yang mendapat skor 81 berjumlah 1 orang $(3,33 \%)$; sampel yang mendapat skor 80,5 berjumlah 1 orang $(3,33 \%)$; sampel yang mendapat skor 80 berjumlah 1 orang $(3,33 \%)$; sampel yang mendapat skor 79 berjumlah 1 orang $(3,33 \%)$; sampel yang mendapat skor 78,5 berjumlah 2 orang $(6,66 \%)$; sampel yang mendapat skor 78 berjumlah 1 orang (3,33\%); sampel yang mendapat skor 77,5 berjumlah 1 orang $(3,33 \%)$; sampel yang mendapat skor 76 berjumlah 2 orang $(6,66 \%)$; sampel yang mendapat skor 74,5 berjumlah 1 orang $(3,33 \%)$; sampel yang mendapat skor 73 berjumlah 1 orang $(3,33 \%)$; sampel yang mendapat skor 72 berjumlah 1 orang $(3,33 \%)$; sampel yang mendapat skor 69,5 berjumlah 1 orang $(3,33 \%)$; dan sampel yang mendapat skor 67,5 berjumlah 1 orang $(3,33 \%)$.

Hasil analisis data kelas kontrol dengan 30 siswa yang dianalisis diperoleh gambaran, yaitu tidak ada siswa yang mampu memperoleh skor 100 sebagai skor maksimal. Skor tertinggi yaitu 79,5 yang diperoleh 1 orang siswa dan skor terendah yang diperoleh 1 siswa adalah 57 .

Skor tertinggi yang diperoleh siswa yaitu 79,5 yang diperoleh 1 orang $(3,33 \%)$; sampel yang mendapat skor 78,5 berjumlah 1 orang $(3,33 \%)$; sampel yang mendapat skor 78 berjumlah 2 orang $(6,66 \%)$; sampel yang mendapat skor 77,5 berjumlah 2 orang $(6,66 \%)$; sampel yang mendapat skor 76,5 berjumlah 1 orang $(6,66 \%)$; sampel yang mendapat skor 75,5 berjumlah 2 orang $(6,66 \%)$; sampel yang mendapat skor 73,7 berjumlah 1 orang $(3,33 \%)$; sampel yang mendapat skor 72 berjumlah 1 orang (3,33\%); sampel yang mendapat skor 71,5 berjumlah 1 orang $(3,33 \%)$; sampel yang mendapat skor 70,5 berjumlah 1 orang $(9,99 \%)$; sampel yang mendapat skor 68 berjumlah 3 orang $(9,99 \%)$; sampel yang mendapat skor 67 berjumlah 1 orang $(3,33 \%)$; sampel yang mendapat skor 65,5 berjumlah 1 orang $(3,33 \%)$; sampel yang mendapat skor 64 berjumlah 1 orang $(3,33 \%)$; sampel yang mendapat skor 63,5 berjumlah 1 orang $(3,33 \%)$; sampel yang mendapat skor 63 berjumlah 1 orang $(3,33 \%)$; sampel yang mendapat skor 62 berjumlah 1 orang (3,33\%); sampel yang mendapat skor 60,5 berjumlah 1 orang $(3,33 \%)$; sampel yang mendapat skor 59,5 berjumlah 1 orang $(3,33 \%)$; dan sampel yang mendapat skor 57 berjumlah 1 orang $(3,33 \%)$.

Hasil analisis data kelas eksperimen, rata-rata hasil tes siswa kelas eksperimen adalah 7,9, sedangkan rata-rata hasil tes siswa kelas kontrol adalah 6,5. Jadi, kelompok yang menerapkan pendekatan kontekstual mempunyai 
kompetensi menulis puisi lebih tinggi daripada kelompok yang tidak menerapkan pendekatan kontekstual dalam pembelajaran menulis puisi siwa kelas X SMA Negeri 1 Wonomulyo, Polewali mandar.

Dari hasil analisis data statistik deskriptif yang diuraikan, terlihat bahwa nilai eksperimen ( $\mathrm{t}$ hitung) yang diperoleh sebesar 4,51 ; d.b. $30-1=29$ pada taraf signifikasi $5 \%$ dan kepercayaan $95 \%$ diperoleh t.s $0,95=1,70$

$\mathbf{t}_{\text {hitung }}=4,51$

$\mathrm{t}_{\text {tabel }}=1,70$

Jadi, $t_{\text {hitung }}>t_{\text {tabel }}$

Hipotesis yang akan diuji dengan statistik uji $\mathrm{t}$ adalah pendekatan kontekstual efektif diterapkan dalam pembelajaran menulis puisi siswa kelas $\mathrm{X}$ SMA Negeri 1 Wonomulyo. Dalam penelitian ini, kelompok siswa yang menerapkan pendekatan kontekstual dalam menulis puisi memilki nilai yang lebih tinggi daripada kelompok siswa yang tidak menerapkan pendekatan kontekstual dalam menulis pusi, maka pengetesan yang dilakukan adalah pengetesan satu arah.

Dalam pengujian statistik, hipotesis ini dinyatakan sebagai berikut:

$$
\mathrm{H}_{0}: \mathrm{th} \leq \mathrm{tt} \quad \text { lawan } \quad \mathrm{Hl}: \mathrm{th} \geq \mathrm{tt}
$$

Setelah dilakukan perhitungan berdasarkan hasil statistik inferensial (eksperimen) jenis uji t diperoleh nilai t hitung 4,51 kriteria pengujiannya adalah: $\mathrm{H}_{0}$ diterima jika thitung $<$ ttabel dan $\mathrm{H}_{0}$ ditolak jika thitung $>$ ttabel. ttabel $=$ d.b-1 $=30-1=29$ pada taraf signifikasi $5 \%$ dan kepercayaan 95\% diperoleh t.s $0,95=1,70$

Ternyata thitung $(4,51)>$ ttabel $(1,70)$

Bedasarkan perhitungan di atas, maka $\mathrm{H}_{0}$ ditolak dan $\mathrm{H}_{1}$ diterima. Jadi, pendekatan kontekstual efektif diterapkan dalam pembelajaran menulis puisi siswa kelas X SMA Negeri 1 Wonomulyo, Polewali mandar.

\section{SIMPULAN}

Simpulan yang terkait dengan hasil penelitian menunjukkan bahwa pendekatan kontekstual efektif diterapkan dalam pembelajaran menulis puisi siswa kelas X SMA Negeri 1 Wonomulyo, Polewali mandar. Hal ini didasarkan pada hasil analisis nilai rata-rata kompetensi menulis puisi siswa, baik pada kelas kontrol maupun kelas eksperimen. Hasil analisis data perbandingan skor rata-rata hasil tes siswa antara kelas eksperimen dan kelas kontrol dengan menggunakan rumus uji $t$ desain ketiga, dapat diketahui bahwa nilai thitung $(4,51)>$ ttabel $(1,70)$, sehingga hipotesis nol $\left(\mathbf{H}_{0}\right)$ ditolak dan hipotesis alternatif $\left(\mathbf{H}_{1}\right)$ diterima. 


\section{SARAN}

Berdasrkan hasil penelitian ini disarankan kepada guru Bahasa Indonesia, khususnya guru kelas X SMA Negeri 1 Wonomulyo agar menerapkan pendekatan kontekstual dalam pembelajaran menulis puisi.

\section{DAFTAR PUSTAKA}

Arikunto, Suharsimi. 2006. Prosedur Penelitian Suatu Pendekatan Praktik. Jakarta: Rineka Cipta

Djumingin, Sulastriningsih. 2007. Strategi Belajar dan Mengajar. Diktat. Makassar: Badan Penerbit: UNM.

Erman, dkk. 2004. Model-model Pembelajaran Matematika. Bandung: LPMP Jawa Barat.

Nurgiyantoro, Burhan. 1995. Penelitian Pengajaran Bahasa dan Sastra. Yogyakarta: BPEE.

Pradopo, Djoko Rachmat. 1987. Pengkajian Puisi. Yogyakarta: Gadjah Mada University Press.

Waluyo, Herman J. 1995. Teori dan Apresiasi Puisi. Jakarta: Erlangga. 